\title{
Growth behaviour and fruit productivity of watermelon as an affected with grafting onto different rootstock genotypes
}

\author{
Abd El-Mageed M. H., Ahmad M. E., Younes N. A.* \\ Horticulture Department, Faculty of Agriculture, Al-Azhar University, Assiut, Egypt
}

\begin{abstract}
The experiments were conducted on watermelon (Citrullus lanatus L.) at an a private farm in Awlad Amr village, Qena city, Qena, Egypt located between $26^{\circ} 10^{\prime} 0^{\prime \prime} \mathrm{N}, 32^{\circ} 43^{\prime} 0^{\prime \prime} \mathrm{E}$ during the two consecutive spring-summer seasons of 2018 and 2019 respectively to study the effect of three different genotypes used as rootstocks on plant growth performance, fruit yield and quality of three watermelon $\mathrm{F}_{1}$ hybrids. Tongue approach grafting method was used, three hybrids of watermelon which growing on a large scale of the commercial production of watermelons in Egypt namely, Aswan $F_{1}$, Misr1 $F_{1}$ and Star $F_{1}$ was grafted onto three different genotype rootstocks i.e. Cobalt $F_{1}$, Ferro $F_{1}$ and New Star $F_{1}$. The experiment was laid out in Randomized Complete Block Design (RCBD) with three replications. Calculated data revealed that, there are clear significant differences between the grafted and non-grafted plants. Results of yield characteristics and its component, such as fruit weight, fruits length and circumferences and total fruit yield per feddan (ton) (feddan $=0.420$ hectares $=1.037$ acres), indicated to the superiority of the Misr $1 F_{1}$ hybrid which grafted onto Cobalt $F_{1}$ rootstock, followed by the Aswan $F_{1}$ when grafted onto Cobalt $F_{1}$ rootstock. On the other side, Ferro $F_{1}$ rootstock was poorly adapted with the all commercial hybrids of watermelon under studies.
\end{abstract}

Keywords: watermelon, rootstock, grafting, tongue approach.

*Corresponding author: Younes N. A., 


\section{Introduction}

Watermelon (Citrullus lanatus L.) a, is herbaceous creeping plant belong to the family cucurbitaceae. It is mainly propagated by seeds and thrives best in warm areas. It is a tropical plant and requires a lot of sunshine and high temperature of over $25^{\circ} \mathrm{C}$ for optimum growth. Watermelon thrives best in a drained fertile soil of fairly acidic nature. The fruit Citrullus lanatus carried 92\% water by weight and about $6 \%$ sugar. It is a very good source of vitamin A, B and C which is necessary for energy production (Alka et al., 2018). Citrullus lanatus (watermelon) produces a fruit that is about $93 \%$ water, hence the name "water" melon. The "melon" part came from the fact that the fruit is large and round and has a sweet, pulpy flesh. The scientific name of the watermelon is derived from both Greek and Latin roots. The Citrullus part comes from a Greek word "citrus" which is a reference to the fruit. The lanatus part is Latin, and has the meaning of being wooly, referring to the small hairs on the stems and leaves of the plant (Baker et al., 2002). Watermelon (Citrullus lanatus Thumb.) is one of the important vegetable crops in Egypt. The major nutritional components of the fruit are carbohydrates, vitamin $\mathrm{A}$ and lycopene, and anti-carcinogenic compound found in red flesh watermelon. Lycopene may help reduce the risk of certain cancer of prostate gland, pancreas and stomach. The total watermelon cultivated area in 2019 in Egypt, was 120,236 fed., which produced 1583918 tons with average 13.17 ton/fed., (FAO, 2019). Vegetable production using grafted plants was first initiated in Japan and Korea in the late 1920s. Grafting has become popular especially in fruitbearing vegetables grown in greenhouses. In 1990, the area using grafted plants accounted for $59 \%$ of the production area of watermelons, cucumbers, eggplants, tomatoes and melons. Grafting is very effective to control soil-borne diseases and nematodes (Oda, 1995). High, yearround demand, increased production intensity without crop rotation, and the loss of Methyl Bromide as a soil fumigant, results in unfavorable soil conditions with increased soil pathogen populations for growing watermelon (Citrullus lanatus Thunb, Matsum and Nakai). Recently, many rootstocks that can be used in grafting process have spread. Certain rootstocks have superior growth habits, disease and insect resistance, and better anchorage. For example, when used as rootstock for commercial apple varieties, some rootstocks can increase resistance to crown gall and root aphids. Some are also used as dwarfing rootstocks. Grafting is an eco-friendly technique which promotes organic vegetable production. In India, Grafting can also helps in the reduction of the problems created by vegetables industry and also reduced the use of fertilizers and pesticides leads to increases in yield and quality of produced also improved. In addition, grafting application helps in reducing in the occurrence of soil borne infections leads to reduction in toxicity level vegetables and environmental pollution (Thakur and Savita, 2020). Grafting is an important integrated pest management strategy to manage soil borne pathogens and other 
pests of solanaceous and cucurbitaceous crops. Important diseases managed by grafting are caused by fungal pathogens such as Verticillium, Fusarium, Pyrenochaeta and Monosporascus (Louws et al., 2010). Vegetable production with grafted seedlings was originated in Japan and Korea to avoid the serious crop loss caused by infection of soil-borne diseases aggravated by successive cropping. This practice is now rapidly spreading and expanding over the world. Vegetable grafting has been safely adapted for the production of organic as well as environmentally friendly produce and minimizes uptake of undesirable agrochemical residues (Mohamed et al., 2014). Grafting is a method which is done in tomato used for solving the problems caused by insect pests, occurrence of weeds and diseases like late blight and Fusarium wilt due to this yield will be reduced (Pogonyi et al. 2005). Grafting is done to control Fusarium wilt and tolerant to drought and flooding. Currently, in cucurbitaceous family watermelon is one crop in which grafting is practiced in the world (Yetisir et al., 2003). Production of vegetables via grafting in Egypt is still in the primary stage. Cucurbits mainly watermelon presents the common vegetables that were propagated through grafted transplants. Under Egyptian conditions, although the higher cost of propagation of watermelon through grafted transplants, the farmers resorted to grafting watermelon to face many problems may severely decline watermelon cultivation area. Increase chemical pollution of soil and water and scarcity of the displayed virgin soil or limited availability of arable land attribute to increase the demand on grafted transplants for watermelon cultivation. Generally, apply grafting in vegetables cultivation in Egypt considers a new and promising practice (El-Kersh et al., 2016). Fruit quality and salinity conditions can be improved by grafting method. Yetisir et al. (2003) observed that, grafting helps in changing the quality of watermelon i.e. fruits size, texture or TSS content mostly depends on which type of rootstock is used. When brinjal grafted on gave negative effect on firmness of fruits, content of vitamin $\mathrm{C}$ but generally their contribution was not very much successful (Arvanitoyannis et al., 2005). Davis et al. (2008) reported that sugars accumulate in the fruit toward the end of fruit development and ripening, depending upon the rootstock-scion combination, while the fruits of grafted and non-grafted plants acquire their rind color at about the same time. This result in growers harvesting too early and those early-harvested fruits tend to be less sweet and have a squash-like flavor. With the help of grafting the content of Sugar, carotene, flavor, color, texture can be affected. Di-Gioia et al. (2010) concluded this with the help of grafting there is change in TSS content when tomato "Oxheart" grafted with Solanum lycopersicum $\times$ Solanum habrochiates and also found that if tomato plants grafted onto Beaufort $F_{1}$ and Maxifort $F_{1}$ vitamin $\mathrm{C}$ content was decreased by 14 20\%. According to Flores et al. (2010), the quality of fruits present on shoot is mainly dependent on the structures of root system. Gebologlu et al. (2011) observed that when tomato grown in soil less cultivation then due to these grafted 
plants gives higher marketable yield, fruit quality. Overall, most rootstocks, except bottle gourd, have been reported to increase watermelon fruit flesh firmness, total soluble solids (TSSs), and lycopene content compared to nongrafted fruit (Alan et al., 2007; Bruton et al., 2009; Kyriacou et al., 2016). Pinki et al. (2020) reported that, grafting can effectively mitigate the adverse effects of environmental stress on watermelon production. Rootstock/scion combinations can influence stress tolerance of grafted plants under different environmental conditions. Hormonal signalling plays an important role in graft union formation, rootstock-scion communication, growth and yield, and potential flowering and fruit quality. Fruit quality measures can be confounded by non-standardization of harvest maturity of grafted and nongrafted plants, and there is need for further research regarding timing of maturation to optimize fruit quality of grafted watermelon. Although the changes in fruit quality after grafting have been widely reported, the mechanisms involved in regulating fruit characteristics with different rootstocks are still unknown. Therefore, the aim of this investigation was to determine the effects of rootstock variation on growth, yield and quality of some watermelon hybrids. Also, to illuminate the importance of carefully selection of rootstock/scion combinations to ensure high quality grafted vegetable fruit.

\section{Materials and methods}

\subsection{Experimental site}

The experiments were conducted on watermelon (Citrullus lanatus L.) at an a private farm in Awlad Amr village, Qena city, Qena, Egypt located between $26^{\circ} 10^{\prime} 0^{\prime \prime} \mathrm{N}, 32^{\circ} 43^{\prime} 0^{\prime \prime} \mathrm{E}$ during the two consecutive spring-summer seasons of 2018 and 2019 respectively to Study the effect of three different genotypes used as rootstocks on plant growth performance, fruit yield and quality of three watermelon $F_{1}$ hybrids used as scion in a clay loam soil as presented in Table (1).

Table (1): The physical and chemical properties of the samples taken from experimental soil during the two cultivated seasons.

\begin{tabular}{|l|c|c|c|}
\hline Characteristic & Value & Characteristic & Value \\
\hline O.M. (\%) & 1.2 & $\mathrm{Cl}$ & 1.65 \\
\hline $\mathrm{CaCO}_{3}(\%)$ & 2.35 & $\mathrm{Mg}^{+2}$ & 5.13 \\
\hline Sand (\%) & 38.3 & $\mathrm{Na}^{+}$ & 10.5 \\
\hline Silt (\%) & 21.8 & $\mathrm{~K}^{+}$ & 0.23 \\
\hline Clay (\%) & 39.9 & Available (ppm) & 2 \\
\hline Texture class & Clay loam & $\mathrm{NH}_{4}$ & 48.0 \\
\hline pH & 7.75 & $\mathrm{~N}$ & 62.4 \\
\hline $\mathrm{EC}(\mathrm{dS} / \mathrm{m})$ & 1.55 & $\mathrm{P}$ & 9.2 \\
\hline Soluble ions (me/L) & - & $\mathrm{K}$ & 356 \\
\hline $\mathrm{CO}_{3}$ & - & $\mathrm{SO}^{-2}$ & 11.45 \\
\hline $\mathrm{HCO}_{3}$ & 8.45 & $\mathrm{Ca}^{+2}$ & 5.40 \\
\hline
\end{tabular}




\subsection{Experimental materials}

\subsubsection{Plant material}

Watermelon, Aswan $F_{1}$, misr $1 F_{1}$ and Star hybrids were used as non-grafting judging elements. These hybrids are grown on a large scale in the commercial production of watermelons in Egypt, and Cobalt $F_{1}$, Ferro $F_{1}$ and New Star $F_{1}$ hybrids were used as a rootstock. Watermelon scion and rootstock seed sources are shown in Table (2).

\subsubsection{Grafting method and experimental design}

The seeds of the rootstocks were sown 10-15 days earlier than the seeds of the scions to ensure similar stem diameters at the grafting time due to the differences in growth vigor. In both cultivated seasons of 2018 and 2019 at 25 December and 10 January seeds of rootstock and scion were sown respectively in 130-cell styrophoam trays under greenhouse conditions in a private nursery of Qena city, Qena, Egypt. The trays were filled with soil mixture (peat moss, vermiculite and perlite mixes in 1:1:1 v/v/v). They were grafted on 15 January 2018 and 2019. Grafted plants were kept in a small tunnel under semi-controlled environmental conditions. Seedlings grew without light and with a $>90 \% \mathrm{RH}$ (Relative Humidity) for four days, then light was gradually increased, and relative humidity was decreased. The environmental conditions for germination were $24-28^{\circ} \mathrm{C}$ and $85-90 \%$ relative humidity. Tongue approach grafting method was the best grafting method for watermelon as reported by Hussien (2011) and was used in this study as described by Hassell et al. (2008). At the two true-leaf stage (10 February of 2018 and 2019), grafted plants were transplanted in rows $3.0 \mathrm{~m}$ wide and $5 \mathrm{~m}$ long, spaced $0.5 \mathrm{~m}$ apart at the open field. During the plant-growing period, furrow irrigation was used. Insecticide was applied to avoid crop damage by cabbage worms and aphids. Weeds were kept under control manually. The experiment was set up in a randomized completely block design (RCBD) with three replicates for each treatment.

Table (2): Watermelon scion and rootstock seed sources and origin country.

\begin{tabular}{|l|c|l|c|}
\hline Rootstock & Hybrid Type & Importing Company & Origin \\
\hline Cobalt $\mathrm{F}_{1}$ & C. maxima X C. moschata & Egypt Company & Netherlands \\
\hline Ferro & C. maxima X C. moschata & Egypt Company & Netherlands \\
\hline New Star & C. maxima X C. moschata & New Star Company & Serbia \\
\hline \multicolumn{3}{|c|}{ Watermelon Hybrid } \\
\hline Hybrid & Importing Company & Origin \\
\hline Aswan $\mathrm{F}_{1}$ & Sakata Company & Japan \\
\hline Misr1 $\mathrm{F}_{1}$ & Islamic Company & India \\
\hline Star $\mathrm{F}_{1}$ & New Star Company & USA \\
\hline
\end{tabular}




\subsubsection{Experimental treatments}

Watermelon hybrid used in this study was grafted onto three genotype rootstocks as follow:

- Aswan F1 (control), Aswan F1 Cobalt F1, Aswan F1\Ferro F1 and Aswan F1\ New Star.

○ Misr1 $F_{1}$ (control), Misr1 $F_{1} \backslash$ Cobalt $F_{1}$, Misr1 $F_{1} \backslash$ Ferro $F_{1}$ and Misr1 $F_{1} \backslash$ New Star.

- Star $F_{1}$ (control), Star $F_{1} \backslash$ Cobalt $F_{1}$, Star $F_{1} \backslash$ Ferro $F_{1}$ and Star $F_{1} \backslash$ New Star.

\subsubsection{Agricultural operations}

Grafted seedlings were initially grown in a greenhouse and fertilized with 19:19:19 for N: P: K soluble fertilizers. During soil preparation a mixture of $1 \mathrm{~m} 3$ of poultry manure $\left(2.5 \% \mathrm{~N}, 1.5 \% \mathrm{P}_{2} \mathrm{O}_{5}\right.$ and $2.1 \% \mathrm{~K}_{2} \mathrm{O}$ ) plus $5 \mathrm{~kg}$ ammonium nitrate $\left(\begin{array}{ll}33.5 \% & \mathrm{~N}\end{array}\right), \quad 20 \mathrm{~kg}$ calcium super phosphate $\left(15.5 \% \mathrm{P}_{2} \mathrm{O}_{5}\right), 5 \mathrm{~kg}$ potassium

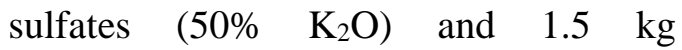
magnesium sulphates were applied as basic fertilizers, for each $200 \mathrm{~m} 2$ of the trials. Two weeks after transplanting a fertigation program was started to complete the fertilization regimes to the levels of $\left(120 \mathrm{~kg} \mathrm{~N}, 100 \mathrm{~kg} \mathrm{P}_{2} \mathrm{O}_{5}\right.$ and 100 $\mathrm{kg} \mathrm{K}_{2} \mathrm{O}$ /feddan) (feddan $=0.420$ hectares $=1.037$ acres). At flowering stage an additional doses of potassium sulfates was divided into three equal parts and applied as top dressing near the roots every 15 days, to reach level of 150 $\mathrm{kg} \quad \mathrm{K}_{2} \mathrm{O}$ /feddan. Fruit thinning was carried out after three weeks from fruit setting, and the selected fruits were remarked, then all female flowers and escaped fruits were removed twice a week. Other cultivation practices were applied to all experiment area during both growing seasons according to the Egyptian Ministry of Agriculture recommendations for the spring-summer season.

\subsubsection{Data Taken}

Harvesting was carried out upon fruit maturity symptoms. All harvested fruits were weighted, then mean fruit weight $/ \mathrm{kg}(\mathrm{FW})$ and total yield ton /feddan (FY) were calculated. Also, fruit length $\mathrm{cm}$ (FL) and fruit circumferences $\mathrm{cm}$ (FC) were measured. Tow medium fruits from each replicate were used to measure average fruit skin thickness (FST) and total soluble solids (TSS) in flesh as fruit quality indicator. As well as plant height $\mathrm{m}(\mathrm{PH})$ and number of branches per plant $(\mathrm{BN} / \mathrm{P})$ was determined at harvesting time.

\subsubsection{Statistical analysis}

Data were subjected to the statistical analysis of ANOVA, and the entries means were compared according to the least significant differences (LSD) at 5\% levels, as reported by Gomez and Gomez (1984). All statistical analysis was performed with MCTAT computer software. 


\section{Results}

Data displayed in Tables (3) and (4) shows the impact of grafting watermelon hybrid Star $F_{1}$, Misr $1 F_{1}$ and Aswan $F_{1}$ on three original rootstocks i.e. Ferro $\mathrm{F}_{1}$, New Star $F_{1}$ and Cobalt $F_{1}$ as well as direct seeded plants of watermelon (without grafting as a control) on plant height and number of branches per plant.
The data clarify that grafting enhanced significantly plant height and branches number per plant compared to nongrafted plants as a control. Among the original rootstocks, it was obvious that rootstock Cobalt $F_{1}$ exceeded New Star $F_{1}$ and Ferro $F_{1}$ rootstocks for plant height, while, Ferro $F_{1}$ exceeded Cobalt $F_{1}$ and New Star $F_{1}$ rootstocks for plant height for branches number per plant.

Table (3): Effect of rootstock on plant height $\mathrm{m}$ of grafted watermelon in hybrids Star $F_{1}$, Misr $1 F_{1}$ and Aswan $F_{1}$.

\begin{tabular}{|l|c|c|c|c|c|c|c|c|}
\hline \multirow{2}{*}{ Scion } & \multicolumn{4}{|c|}{$2018 / 2019$} & \multicolumn{4}{c|}{$2019 / 2020$} \\
\cline { 2 - 10 } Rootstock & Star $\mathrm{F}_{1}$ & Misr 1 $\mathrm{F}_{1}$ & Aswan $\mathrm{F}_{1}$ & Means b & Star $_{\mathrm{F}}$ & Misr 1 $\mathrm{F}_{1}$ & Aswan $\mathrm{F}_{1}$ & Means b \\
\hline Ferro $\mathrm{F}_{1}$ & 3.24 & 3.67 & 3.57 & 3.49 & 3.33 & 3.73 & 3.72 & 3.60 \\
\hline New Star $\mathrm{F}_{1}$ & 3.31 & 3.38 & 3.38 & 3.36 & 3.30 & 3.70 & 3.59 & 3.53 \\
\hline Cobalt $\mathrm{F}_{1}$ & 2.87 & 3.30 & 3.45 & 3.21 & 3.01 & 3.49 & 3.12 & 3.21 \\
\hline Check & 1.66 & 2.76 & 2.13 & 2.18 & 1.83 & 2.26 & 2.84 & 2.31 \\
\hline Means a & 2.77 & 3.28 & 3.13 & --- & 2.87 & 3.30 & 3.31 & --- \\
\hline LSD & \multicolumn{9}{|c|}{$\mathrm{a}=0.15 \quad \mathrm{~b}=0.17 \mathrm{ab}=0.29$} & \multicolumn{3}{c|}{$\mathrm{a}=0.24 \quad \mathrm{~b}=0.29 \quad \mathrm{ab}=0.31$} \\
\hline
\end{tabular}

Table (4): Effect of rootstock on branches number per plant of grafted watermelon in hybrids Star $F_{1}$, Misr $1 F_{1}$ and Aswan $F_{1}$.

\begin{tabular}{|l|c|c|c|c|c|c|c|c|}
\hline \multirow{2}{*}{ Scion } & \multicolumn{4}{|c|}{$2018 / 2019$} & \multicolumn{4}{c|}{$2019 / 2020$} \\
\cline { 2 - 10 } & Star $\mathrm{F}_{1}$ & Misr $1 \mathrm{~F}_{1}$ & Aswan $\mathrm{F}_{1}$ & Means b & Star $\mathrm{F}_{1}$ & Misr 1 $\mathrm{F}_{1}$ & Aswan $\mathrm{F}_{1}$ & Means b \\
\hline Ferro $\mathrm{F}_{1}$ & 9.0 & 6.4 & 8.6 & 8.0 & 9.6 & 7.0 & 8.9 & 8.5 \\
\hline New Star $\mathrm{F}_{1}$ & 9.3 & 7.0 & 8.2 & 8.2 & 10.0 & 7.8 & 8.8 & 8.9 \\
\hline Cobalt $\mathrm{F}_{1}$ & 9.2 & 8.6 & 8.4 & 8.7 & 10.0 & 9.4 & 9.3 & 9.9 \\
\hline Check & 5.9 & 5.8 & 6.6 & 6.1 & 6.2 & 4.8 & 6.2 & 5.7 \\
\hline Means a & 8.4 & 7.0 & 8.0 & --- & 9.0 & 7.2 & 8.3 & --- \\
\hline LSD & \multicolumn{3}{|c|}{$\mathrm{a}=0.63 \quad \mathrm{~b}=0.73 \quad \mathrm{ab}=1.26$} & \multicolumn{3}{c}{$\mathrm{a}=0.58 \mathrm{~b}=0.67 \quad \mathrm{ab}=2.11$} \\
\hline
\end{tabular}

Analysis of the results obtained from Tables (5, 6, 7 and 8) refers to the influence of grafting watermelon on average fruit weight $\mathrm{kg}$, fruit length $\mathrm{cm}$, fruit circumference $\mathrm{cm}$ and total fruit yield as ton per feddan. The results showed significantly differences in all grafted and non-grafted plants. Misr $1 \mathrm{~F}_{1}$ hybrid recorded the best response to the fruit traits i.e., fruit weight $\mathrm{kg}$, fruit length $\mathrm{cm}$, fruit circumference $\mathrm{cm}$ and total fruit yield ton /feddan compared to the other hybrids. On the other hand, Cobalt $\mathrm{F}_{1}$ rootstock was the best in combination with watermelon hybrids. Misr $1 \quad F_{1}$ /Cobalt $F_{1}$ gave the highest values of fruit traits $\mathrm{kg}$ followed by Aswan $\mathrm{F}_{1} /$ Cobalt $\mathrm{F}_{1}$ in both seasons. 
Table (5): Effect of rootstock on fruit weight $\mathrm{kg}$ of grafted watermelon in hybrids Star $\mathrm{F}_{1}$, Misr $1 \mathrm{~F}_{1}$ and Aswan $\mathrm{F}_{1}$.

\begin{tabular}{|l|c|c|c|c|c|c|c|c|}
\hline \multirow{2}{*}{ Scion } & \multicolumn{4}{|c|}{$2018 / 2019$} & \multicolumn{4}{c|}{$2019 / 2020$} \\
\cline { 2 - 9 } Rootstock & Star $F_{1}$ & Misr 1 $F_{1}$ & Aswan $F_{1}$ & Means b & Star $F_{1}$ & Misr 1 $F_{1}$ & Aswan $F_{1}$ & Means b \\
\hline Ferro F $F_{1}$ & 8.2 & 8.6 & 8.6 & 8.5 & 8.7 & 9.6 & 9.3 & 9.20 \\
\hline New Star $F_{1}$ & 9.0 & 9.8 & 8.8 & 9.2 & 9.0 & 9.4 & 9.5 & 9.3 \\
\hline Cobalt F & 9.4 & 10.4 & 9.9 & 9.9 & 9.6 & 10.8 & 9.8 & 10.2 \\
\hline Check & 7.6 & 8.0 & 7.7 & 7.8 & 8.3 & 8.4 & 7.4 & 8.0 \\
\hline Means a & 8.6 & 9.2 & 8.8 & --- & 8.9 & 9.6 & 9.0 & --- \\
\hline LSD & \multicolumn{3}{|c|}{$\mathrm{a}=0.22 \quad \mathrm{~b}=0.25 \mathrm{ab}=0.21$} & \multicolumn{5}{c|}{$\mathrm{a}=0.12 \quad \mathrm{~b}=0.14 \mathrm{ab}=0.24$} \\
\hline
\end{tabular}

Table (6): Effect of rootstock on fruit length $\mathrm{cm}$ of grafted watermelon in hybrids Star $\mathrm{F}_{1}$, Misr $1 \mathrm{~F}_{1}$ and Aswan $\mathrm{F}_{1}$.

\begin{tabular}{|c|c|c|c|c|c|c|c|c|}
\hline \multirow{2}{*}{$\begin{array}{l}\text { Scion } \\
\text { Rootstock }\end{array}$} & \multicolumn{4}{|c|}{$2018 / 2019$} & \multicolumn{4}{|c|}{$2019 / 2020$} \\
\hline & Star $F_{1}$ & Misr $1 \mathrm{~F}_{1}$ & Aswan $F_{1}$ & Means b & Star $F_{1}$ & Misr $1 \mathrm{~F}_{1}$ & Aswan $F_{1}$ & Means b \\
\hline Ferro $F_{1}$ & 33.5 & 36.5 & 34.5 & 34.8 & 32.6 & 35.5 & 33.4 & 33.8 \\
\hline New Star $F_{1}$ & 34.8 & 37.3 & 35.2 & 35.8 & 33.9 & 36.7 & 34.6 & 35.1 \\
\hline Cobalt $F_{1}$ & 35.7 & 39.0 & 36.9 & 37.2 & 34.4 & 38.7 & 36.0 & 36.4 \\
\hline Check & 31.6 & 33.4 & 32.5 & 32.5 & 30.4 & 33.8 & 31.8 & 32.0 \\
\hline Means a & 33.9 & 36.6 & 34.7 & --- & 32.8 & 36.2 & 33.9 & $-\overline{---}$ \\
\hline LSD & \multicolumn{4}{|c|}{$a=1.31 \quad b=1.51 \quad a b=2.61$} & \multicolumn{4}{|c|}{$a=1.81 \quad b=2.088 \quad a b=3.62$} \\
\hline
\end{tabular}

Table (7): Effect of rootstock on fruit circumference $\mathrm{cm}$ of grafted watermelon in hybrids Star $F_{1}$, Misr $1 F_{1}$ and Aswan $F_{1}$.

\begin{tabular}{|c|c|c|c|c|c|c|c|c|}
\hline \multirow{2}{*}{$\begin{array}{l}\text { Scion } \\
\text { Rootstock }\end{array}$} & \multicolumn{4}{|c|}{$2018 / 2019$} & \multicolumn{4}{|c|}{$2019 / 2020$} \\
\hline & Star $F_{1}$ & Misr $1 \mathrm{~F}_{1}$ & Aswan $\mathrm{F}_{1}$ & Means b & Star $F_{1}$ & Misr $1 \mathrm{~F}_{1}$ & Aswan $\mathrm{F}_{1}$ & Means b \\
\hline Ferro $F_{1}$ & 32.5 & 35.4 & 34.4 & 34.6 & 32.1 & 37.2 & 36.4 & 35.2 \\
\hline New Star $F_{1}$ & 34.5 & 38.2 & 34.8 & 35.9 & 33.2 & 39.4 & 37.0 & 36.5 \\
\hline Cobalt $F_{1}$ & 36.7 & 37.2 & 36.7 & 36.9 & 36.6 & 39.7 & 38.8 & 38.4 \\
\hline Check & 30.4 & 31.3 & 32.4 & 31.4 & 29.9 & 32.4 & 31.8 & 31.3 \\
\hline Means a & 33.5 & 35.5 & 34.6 & ---- & 32.8 & 37.2 & 36.0 & ---- \\
\hline LSD & \multicolumn{4}{|c|}{$a=1.31 \quad b=1.51 \quad a b=2.61$} & \multicolumn{4}{|c|}{$a=1.81 \quad b=2.09 \quad a b=3.62$} \\
\hline
\end{tabular}

Table (8): Effect of rootstock on fruit yield ton/feddan circumference $\mathrm{cm}$ of grafted watermelon in hybrids Star $F_{1}$, Misr $1 F_{1}$ and Aswan $F_{1}$.

\begin{tabular}{|l|c|c|c|c|c|c|c|c|}
\hline \multirow{2}{*}{ Scion } & \multicolumn{4}{|c|}{$2018 / 2019$} & \multicolumn{3}{c|}{$2019 / 2020$} \\
\cline { 2 - 9 } Rootstock & Star $F_{1}$ & Misr 1 F & Aswan $F_{1}$ & Means b & Star $F_{1}$ & Misr 1 $F_{1}$ & Aswan $F_{1}$ & Means b \\
\hline Ferro F $F_{1}$ & 50.0 & 52.6 & 49.2 & 50.6 & 52.3 & 54.8 & 52.0 & 53 \\
\hline New Star $F_{1}$ & 55.8 & 57.6 & 53.3 & 55.6 & 57.5 & 58.6 & 53.9 & 56.7 \\
\hline Cobalt F 1 & 56.5 & 58.02 & 55.7 & 56.7 & 57.9 & 60.9 & 55.5 & 58.1 \\
\hline Check & 30.2 & 38.3 & 31.77 & 33.4 & 33.3 & 38.0 & 32.6 & 34.7 \\
\hline Means a & 48.1 & 51.6 & 47.5 & --- & 50.2 & 53.1 & 48.5 & --- \\
\hline LSD & \multicolumn{3}{|c|}{$\mathrm{a}=2.17 \mathrm{~b}=2.51 \mathrm{ab}=4.35$} & \multicolumn{5}{c|}{$\mathrm{a}=4.25 \mathrm{~b}=4.91 \mathrm{ab}=3.61$} \\
\hline
\end{tabular}


Meanwhile, hybrid plants which grafted onto Ferro $F_{1}$ scored the lowest response for fruit traits to scion /rootstock combination in both seasons. Data presented in Tables 9 and 10 illustrated that grafted hybrids of watermelon plants onto Ferro F1, New Star F1 and Cobalt $\mathrm{F} 1$ rootstocks had not significant affect fruit skin thickness in both seasons, but it was significantly affects on fruit TSS. the greatest values of TSS were recorded by watermelon grafting onto Cobalt $\mathrm{F}_{1}$ rootstock in both seasons. While grafted plants onto Ferro $F_{1}$ gave the lowest values in both seasons. Furthermore, own rooted plants nearly occupied intermediate rank among different treatments in both seasons. Grafting Star $F_{1}$ onto Cobalt $F_{1}$ followed by Aswan $F_{1}$ onto Cobalt $F_{1}$ scored the heights values of watermelon fruit TSS in both seasons. While, Misr $1 F_{1}$ onto Ferro $F_{1}$ recorded the lowest values of watermelon fruit TSS in both seasons.

Table (9): Effect of rootstock on fruit skin thickness of grafted watermelon in hybrids Star $F_{1}$, Misr $1 F_{1}$ and Aswan $F_{1}$.

\begin{tabular}{|l|c|c|c|c|c|c|c|c|}
\hline \multirow{2}{*}{ Scion } & \multicolumn{5}{c|}{$2018 / 2019$} & \multicolumn{4}{c|}{$2019 / 2020$} \\
\cline { 2 - 10 } Rootstock & Star $\mathrm{F}_{1}$ & Misr 1 $\mathrm{F}_{1}$ & Aswan $\mathrm{F}_{1}$ & Means b & Star $_{1}$ & Misr 1 $\mathrm{F}_{1}$ & Aswan $\mathrm{F}_{1}$ & Means b \\
\hline Ferro $\mathrm{F}_{1}$ & 1.51 & 1.70 & 1.6 & 1.60 & 1.51 & 1.65 & 1.64 & 1.60 \\
\hline New Star $\mathrm{F}_{1}$ & 1.49 & 1.67 & 1.62 & 1.60 & 1.50 & 1.59 & 1.64 & 1.57 \\
\hline Cobalt $\mathrm{F}_{1}$ & 1.42 & 1.58 & 1.70 & 1.57 & 1.50 & 1.61 & 1.58 & 1.54 \\
\hline Check & 1.35 & 1.49 & 1.28 & 1.37 & 1.33 & 1.50 & 1.26 & 1.37 \\
\hline Means a & 1.44 & 1.61 & 1.55 & --- & 1.46 & 1.59 & 1.51 & --- \\
\hline LSD & \multicolumn{3}{|c|}{$\mathrm{a}=\mathrm{ns} \mathrm{b}=\mathrm{ns}$ ab=ns } & \multicolumn{5}{c}{$\mathrm{a}=\mathrm{ns}$ b=ns $\mathrm{ab}=\mathrm{ns}$} \\
\hline
\end{tabular}

Table (10): Effect of rootstock on fruit TSS of grafted watermelon in hybrids Star $F_{1}$, Misr $1 \mathrm{~F}_{1}$ and Aswan $\mathrm{F}_{1}$.

\begin{tabular}{|c|c|c|c|c|c|c|c|c|}
\hline \multirow{2}{*}{\begin{tabular}{|c|} 
Scion \\
Rootstock
\end{tabular}} & \multicolumn{4}{|c|}{$2018 / 2019$} & \multicolumn{4}{|c|}{$2019 / 2020$} \\
\hline & Star $F_{1}$ & Misr 1 $F_{1}$ & Aswan $F_{1}$ & Means b & Star $F_{1}$ & Misr $1 \mathrm{~F}_{1}$ & Aswan $F_{1}$ & Means b \\
\hline Ferro $F_{1}$ & 9.83 & 9.56 & 9.78 & 9.72 & 10.2 & 9.70 & 9.83 & 9.72 \\
\hline New Star $F_{1}$ & 9.94 & 9.70 & 9.84 & 9.85 & 10.1 & 9.51 & 9.78 & 9.78 \\
\hline Cobalt $F_{1}$ & 10.38 & 9.67 & 9.93 & 9.96 & 10.4 & 9.22 & 10.05 & 9.90 \\
\hline Check & 9.61 & 8.78 & 9.23 & 9.20 & 9.39 & 9.55 & 9.39 & 9.44 \\
\hline Means a & 9.94 & 9.41 & 9.70 & -- & 10.00 & 9.36 & 9.76 & --- \\
\hline LSD & \multicolumn{4}{|c|}{$\mathrm{a}=\mathrm{ns} \quad \mathrm{b}=0.14 \quad \mathrm{ab}=0.88$} & \multicolumn{4}{|c|}{$\mathrm{a}=\mathrm{ns} \quad \mathrm{b}=0.19 \quad \mathrm{ab}=0.50$} \\
\hline
\end{tabular}

\section{Discussion}

Growth attributes results were presented in Tables (3) and (4). The result of the study revealed that among growth parameters length of the main vine and number of branches per plant was significantly higher in grafted plants than that of non-grafted plants. Vigorous plant growth in grafted watermelon was observed in several studies (Boughalleb et al., 2008; Mohamed et al., 2012; Tarchoun et al., 2005; Yetisir et al., 2007). Promoted watermelon plant growth in the grafted plants can be explained by the interaction of some or all 
of the following phenomena: increased water and plant nutrient uptake (Pulgar et al., 2000), due to stronger and more extensive root growth of the rootstock (bottle gourd), augmented endogenous hormone production (Zijlstra et al., 1994), enhanced scion vigor (Leoni et al., 1990). Data of fruit weight are presented in Table (5) revealed that, fruit weight $\mathrm{kg}$ was significantly influenced by grafting. Our result agrees with those of Ozlem et al. (2007) and El-sayed et al. (2014). Also, Petropoulos et al. (2012) stated that mean fruit weight at harvest was higher in grafted watermelon plants than in selfrooted others. Our results of fruit quality were in accordance with those of Salam et al. (2002) which reinforced a marked increase in watermelon fruit TSS content when grafted onto bottle gourd. Yetisir et al. (2003) found that the soluble solids contents were affected significantly by the rootstock. Ozlem et al. (2007) stated that fruit rind thickness did not affected by grafting watermelon on pumpkin and bottle gourd rootstocks under either open field or low tunnel growing conditions whoever, fruit total soluble content (TSS) was decreased by grafting compared to non-grafting not for all rootstocks under open field conditions but under low tunnels TSS did not impacted by grafting or non-grafting. On muskmelon, findings by Yi-Fei, et al. (2011) revealed that grafting muskmelon plants enhanced the net photosynthesis rate, carbohydrates contents and translocation of sugars in muskmelon leaves. Otherwise, Miguel et al. (2004) did not find any difference in TSS of watermelon fruit from grafted and non- grafted others. Meanwhile, Turhan et al. (2012) found that grafting watermelon on three squash hybrid rootstocks led to decrease total sugars and total soluble solids but increase rind thickness of fruits than non- grafting. Also, Petropoulos et al. (2012) stated that in grafted watermelon, fruit sugar content varied with scion-rootstock combination. The performance of grafting in total fruit yield increasing as shown in Table (8) during both seasons may be due to the strong vegetative growth and higher average fruit weight comparing to non-grafted plants. In this concern, many authors proved that grafting affected fruit yield of watermelon (Alan et al., 2007; Besri, 2008; Rouphael et al., 2008). Islam et al. (2013) state that fruit yield of grafted watermelon was increased one and half times more than non-grafted plants. Sakata et al. (2005) reported that yield and fruit weight of grafted watermelons onto Shintosa rootstock were higher than those with other rootstocks. On the other hand, Yetisir et al. (2003) compared the effects of different rootstocks [squash interspecific hybrids (Cucurbita moschata $\times$ Cucurbita maxima) and bottle gourd (Lagenaria siceraria)] on fruit yield of watermelon. The results cleared the grafted plants onto bottle gourd produced $27-106 \%$ greater yield over control plants, but the Cucurbita sp. rootstock decreased yield by $127-240 \%$. Colla et al . (2006) and Yetisir et al. (2003) reported that the lowest yield recorded in own rooted watermelons associated with a decrease in both average fruit weight and the number of fruits per plant compared to grafted plants. Further, grafting can increase yield since grafted plants are resistant to soil-borne disease, have strong root systems, and increased photosynthesis (Qi et al., 2006; Wu et al., 2006; $\mathrm{Xu}$ et al., 2005). 


\section{Conclusion}

According to the obtained results in this study, watermelon grafting onto Cobalt $F_{1}$ rootstock the best treatment that could be recommended to obtain the highest yield and improve fruit quality of watermelon in Qena province, Egypt and other regions with similar agroclimatic conditions. Also, these results showed that using specific rootstock to graft watermelon influences growth, yield and, sometimes, fruit quality. Moreover, these results may be raising the awareness of Egyptian growers to use the grafted watermelons.

\section{References}

Alan, O., Zdemir, N. and Gunen, Y. (2007), "Effect of grafting on watermelon plant growth, yield and quality", Journal of Agronomy, Vol. 6 No. 2, pp. 362-365.

Alka, G., Anamika, S. and Ranu, P. (2018), "A review on watermelon (Citrullus lanatus) medicinal seeds", Journal of Pharmacognosy and Phytochemistry, Vol. 7 No. 3, pp. 2222-2225.

Arvanitoyannis, S. I., Khah, E. M. Christakou, E. C. and Bletsos, F. A. (2005), "Grafting techniques in vegetable crops: A review", International Journal of Food Science and Technology, Vol. 40, pp. 311-322.

Baker, T. P., Corwin, B., Jett, L. W. (2002), Watermelon Bacterial Fruit Blotch, University of Missouri
Extension, Columbia, USA.

Besri, M. (2008), Cucurbits grafting as alternative to methyl bromide for cucurbits production in Morocco, Research Conference on Methyl Bromide Alternatives and Emissions Reduction Proceedings of the $14^{\text {th }}$ International, Orlando, Florida, USA, pp. 60-61.

Boughalleb, N., Mhamdi, M., El Assadi, B., El Bourgi, Z., Tarchoun, N. and Romdhani, M. S. (2008), "Resistance evaluation of grafted watermelon (Citrullus lanatus L.) against Fusarium wilt and Fusarium crown and root rot", Asian Journal of Plant Pathology, Vol. 2, pp. 2429.

Bruton, B. D., Fish, W. W., Roberts, W., Popham, T. W. (2009), "The influence of rootstock selection on fruit quality attributes of watermelon", The Open Food Science Journal, Vol. 3, pp. 15-34.

Colla, G., Roupahel, Y., Cardarelli, M. and Rea, E. (2006), "Effect of salinity on yield, fruit quality, leaf gas exchange, and mineral composition of grafted watermelon plants", Scientia Horticulturae, Vol. 41 No. 3, pp. 622-627.

Davis, A. R., Perkins-Veazie, P., Hassell, R., Levi, A., King, S. R., Zhang, X. (2008), "Grafting Effects on Vegetable Quality", Hortscience, Vol. 43 No. 6, pp. 670-1672.

Di-Gioia, F., Serio, F., Buttaro, D., 
Ayala, O., Santamaria, P. (2010), "Influence of rootstock on vegetative growth, fruit yield and quality in 'Cuore di Bue', an heirloom tomato", Journal of Horticultural Sciences and Biotechnology, Vol. 85 No. 6, pp. 477-482.

El-Kersh, M. A. A., El-Meniawy, S. M. and Abd El-Hady, S. A. (2016), "Grafting Can Modulate Watermelon Growth and Productivity under Egyptian Conditions", Journal of Plant Production, Vol. 7 No. 9, pp. 915922.

El-Sayed S. F., Hassan, H. A., AbdelWahab A. A. and Gebrael, A. A. (2014), "Effect of grafting on the cucumber yield and quality under high and low temperatures", Journal of Plant Production, Vol. 5, pp. 443-456.

FAO (2019), Agricultural data FAOSTAT, Food and Agriculture Organization of the United Nations, Rome, Italy.

Flores, F. B., Sanchez-Bel, P., Estan, M. T., Morales, B., Campos, J. F. and Egea, M. I. (2010), "The effectiveness of grafting to improve tomato fruit quality", Scientia Horticulturae, Vol. 125, pp. 211217.

Gebologlu, N., Yilmaz, E., Cakmak, P., Aydin, M. and Kasap, Y. (2011), "Determining of the yield, quality and nutrient content of tomatoes grafted on different rootstocks in soilless culture", Science of Research. and Essays, Vol. 6 No. 10, pp. 2147-2153.

Gomez, K. A. and Gomez A. A. (1984), Statistical procedure for agriculture research, $2^{\text {nd }}$ Ed., John Wily \& Sons Inc., New York, USA.

Hassell R. L. and Memmott F. (2008), "Grafting methods for watermelon production", Scientia Horticulture, Vol. 43 No. 6, pp. 1677-1679.

Hussien, M. N. (2011), Studies on grafting in some vegetable crops, M.Sc. Thesis, Department of Horticulture, Faculty of Agriculture, Suez Canal University, Egypt.

Islam, M. S., Bashar, H., Howlader, M., Sarker, J. and Al-Mamun, M. (2013), "Effect of grafting on watermelon growth and yield", Khon Kaen Agriculture Journal, Vol. 41 No. 1, pp. 284-289.

Kyriacou, M. C., Soteriou, G. A., Rouphael, Y., Siomos, A. S., Gerasopoulos, D. (2016), "Configuration of watermelon fruit quality in response to rootstockmediated harvest maturity and postharvest storage", Journal of the Science of Food and Agriculture, Vol. 96 pp. 2400-2409.

Leoni, S., Grudina, M., Madeddu, B. and Carletti, M. G. (1990), "The influence of four rootstocks on some melon hybrids and a cultivar in greenhouse", Acta Horticulturae, 
Vol. 287, pp. 127-134.

Louws, F. J., Rivard, C. L. and Kubota, C. (2010), "Grafting fruiting vegetables to manage soil-borne pathogens, foliar pathogens, arthropods and weeds", Scientia Horticulturae, Vol. 127, pp. 127146.

Miguel, A., Maroto, J. V., San Bautista, A., Baixauli, C., Cebolla, V., Pascual, B., Lopez-Gala, S. and Guardiola, A. J. L. (2004), "The grafting of triploid watermelon is an advantageous alternative to oil fumigation", Scientia Horticulture, Vol. No. 1, 103 pp. 9-17.

Mohamed F. H., El-Hamed, K. E. A., Elwan, M. W. M. and Hussien, M. A. N. E. (2012), "Impact of grafting on watermelon growth, fruit yield and quality", Vegetable Crops Research Bulletin, Vol. 76 No. 7, pp. 99-118.

Mohamed, F. H., Abd El-Hamed, K. E., Elwan, M. W. M. and Hussien, M. N. E. (2014), "Evaluation of different grafting methods and rootstocks in watermelon grown in Egypt", Scientia Horticulture, Vol. No. 1, pp. 168:145-150.

Oda, M. (1995), " New grafting methods for fruit-bearing vegetables in Japan", Japan Agricultural Research Quarterly, Vol. 29, pp. 187-194.

Ozlem, A., Ozdemir, N. and Gunen, Y. (2007), "Effect of grafting on watermelon plant growth, yield and quality", Journal of Agronomy, Vol. 6, pp. 362-365.

Petropoulosa, S. A., Khahb, E. M. and Passam, H. C. (2012), "Evaluation of rootstocks for watermelon grafting with reference to plant development, yield and fruit quality", International Journal of Plant Production, Vol. 6 No. 4, pp. 1735-6814

Pinki, D., Perkins-Veazie, P. and Miles, C. (2020), "Impact of grafting on watermelon fruit maturity and quality", Horticulturae, Vol. 6 No. 12, pp. 97.

Pogonyi, Á., Pék, Z., Helyes, L. and Lugasi, A. (2005), "Effect of grafting on tomato's yield, quality and main fruit components in spring forcing", Acta Alimentaria, Vol. 34 No. 4, pp. 453-462.

Pulgar, G., Villora, G., Moreno, D. A., Romero, L. (2000), "Improving the mineral nutrition in grafted watermelon plants: Nitrogen metabolism", Biologia Plantarum, Vol. 43 No. 4, pp. 607-609.

Qi, H. Y., Li, T. L., Liu, Y. F. and Li, D. (2006), "Effects of grafting on photosynthesis characteristics, yield and sugar content in melon", Journal of Shenyang Agricultural University, Vol. 37 No. 2, pp. 155158.

Rouphael, Y., Cardarelli, M., Colla, G. and Rea, E. (2008), "Yield, mineral composition, water relations and 
water use efficiency of grafted miniwatermelon plants under deficit irrigation", American Society and Horticultural Science, Vol. 43 No. 1, pp. 730-736.

Sakata, Y., Ohara, T. and Sugiyama, M. (2005), "The history and present state of the grafting of cucurbitaceous vegetables in Japan", Acta Horticulturae, Vol. 731, pp. 159-170.

Salam M. A., Masum, A. S., Chowdhury, M. H., Monoranjan, S. S. DharSaddeque, M. A. and Islam, M. R. (2002), "Growth and yield of watermelon as influenced by grafting", On Line Journal of Biological Sciences, Vol. 2 No. 5, pp. 298-299.

Tarchoun, N., Boughalleb, N. and El Mbarki, A. (2005), "Agronomic evaluation of nine cucurbit rootstocks and watermelon grafted (Citrullus lanatus T.) ", Revue de l'INAT, Vol. 20, pp. 125-140.

Thakur, D. and Savita (2020), "Role of grafting in vegetable crops: A review", Journal of Pharmacognosy and Phytochemistry, Vol. 9 No. 6, pp. 1170-1174.

Turhan, A., Ozmen, N., Kuscu, H., Serbeci, M. S. and Seniz, V. (2012), "Influence of rootstocks on yield and fruit characteristics and quality of watermelon",

Horticulture, Environment, and Biotechnology, Vol. 53 No. 4, pp. 336-341.
Wu, Y., Chen, Y. and Zhao, Y. (2006), "Effect of pumpkin stocks on growth, development, yield, and quality of grafted muskmelon", Fujian Journal of Agricultural Sciences, Vol. 21, pp. 354-359.

$\mathrm{Xu}, \mathrm{C} ., \mathrm{Li}, \mathrm{T} ., \mathrm{Qi}, \mathrm{H}$. and Wang, H. (2005), "Effects of grafting on growth and development, yield, and quality of muskmelon", China Vegetables, Vol. 6 pp. 12-14.

Yetişir, H., Kurt, S., Sari, N. and Tok, F. M. (2007), "Rootstock potential of Turkish Lagenaria siceraria germplasm for watermelon: Plant growth, graft compatibility, and resistance to Fusarium", Turkish Journal of Agricultural and Forestry, Vol. 31 No. 6, pp. 381388.

Yetisir, H., Sari, N. and Yncel, S. (2003), "Rootstock resistance to Fusarium wilt and effect on watermelon fruit yield and quality", Phytoparasitica, Vol. 31 No. 2, pp. 163-169.

Yi-Fei, L., Hong-Yan, Q., Chun-Ming, B., Ming-Fang, Q., Chuan-Qiang, X., JingHong, H., Yan, L. and TianLai, V. (2011), "Grafting Helps improve photosynthesis and carbohydrate metabolism in leaves of muskmelon", International Journal of Biological Sciences, Vol. 7 No. 8, pp. 1161-1170.

Zijlstra, S., Groot, S. P. C. and Jansen, J. (1994), "Genetic variation of rootstocks for growth and production in cucumber; pos- 
Abd El-Mageed et al. / Archives of Agriculture Sciences Journal 4(1) 265-279, 2021.

sibilities for improving the root system by plant breeding", Scientia Horticulture, Vol. 56 No. 1, pp. 185-196. 